\title{
TINGKAT PARTISIPASI MASYARAKAT DALAM PELESTARIAN KAMPUNG KAUMAN SURAKARTA
}

\author{
Level of Community Participation in the Conservation of Kampung \\ Kauman Surakarta
}

\author{
Rahardian Maulana ${ }^{1}$, Nurini $^{1}$
}

Diterima: 6 September 2018

Disetujui: 17 Oktober 2018

\begin{abstract}
Abstrak: Kampung Kauman merupakan perkampungan yang terletak di tengah kota dengan kekayaan budayanya serta memiliki potensi bersejarah baik dari segi fisik lingkungan berupa bangunan kuno yang masih terjaga keasliannya maupun tradisi masyarakat dengan kekhasan religius Terdapat berbagai peninggalan bangunan kuno yang masih terawat dengan baik, namun tidak sedikit pula bangunan kuno yang tidak terawat dengan baik dan tidak ditetapkan sebagai bangunan cagar budaya sehingga perlu dilestarikan agar eksistensinya tetap terjaga. Pelestarian dengan pendekatan bottom up merupakan pelestarian yang melibatkan partisipasi masyarakat dalam setiap kegiatannya. Upaya pelestarian dengan melibatkan partisipasi masyarakat dinilai lebih efektif karena mampu menumbuhkan rasa memiliki yang kuat. Tujuan penelitian ini adalah menganalisis tingkat partisipasi masyarakat dalam pelestarian Kampung Kauman sebagai kampung bersejarah di Kota Surakarta serta mengetahui faktor yang mempengaruhinya. Teknik analisis yang digunakan meliputi analisis deskriptif kuantitatif dengan menggunakan metode tabulasi silang dan uji chi square. Berdasarkan analisis tabulasi silang dan uji chi square yang telah dilakukan, faktor internal yang memiliki hubungan dengan bentuk dan tingkat partisipasi masyarakat antara lain jenis kelamin, tingkat pendidikan, dan lama tinggal. Sedangkan faktor eksternal yang memiliki hubungan dengan bentuk dan tingkat partisipasi masyarakat adalah peran pihak kelurahan, tokoh masyarakat, dan paguyuban.
\end{abstract}

Kata kunci : partisipasi masyarakat, pelestarian, kampung kota

Abstract: Kampung Kauman is located in the center of the city that has a wealth of culture and has a historical potential both in terms of physical environment and in the form of ancient buildings that are still authentic and traditions of society with religious distinctiveness. There are various relics of ancient buildings that are still well maintained, but there are ancient buildings that are not well maintained and not defined as a cultural heritage building so it needs to be preserved so that its authenticity is maintained. Conservation with a bottom up approach is a preservation that involves community participation in every activity. Conservation by involving community participation are considered more effective because it is able to grow a strong sense of belonging. The purpose of this study is to analyze the level of community participation in the conservation of Kampung Kauman as a historic place in the city of Surakarta and know the factors that influence it. Analytical techniques used include descriptive quantitative analysis using cross tabulation method and chi square test. Based on analysis of cross tabulation and chi square test that has been done, internal factors that have relationship with form and level of society participation are gender, education level, and length of stay. While external factors that have a relationship with the shape

\footnotetext{
${ }^{1}$ Departemen Perencanaan Wilayah dan Kota, Fakultas Teknik, Universitas Diponegoro
} 
and level of community participation is the role of the kelurahan, community figure, and paguyuban Batik Kauman.

Keywords: community participation, conservation, kampung kota

\section{PENDAHULUAN}

Partisipasi masyarakat adalah keterlibatan seseorang atau suatu kelompok masyarakat secara aktif dalam berkontribusi secara sukarela pada sebuah program. Suatu partisipasi masyarakat diperlukan sebagai pertimbangan dalam pengambilan keputusan (Omar et al., 2016). Sedangkan menurut Kayat (2002) dalam Prabhakaran et al. (2014), keterlibatan masyarakat semata-mata bukan tentang afiliasi antara pemerintah dan masyarakat setempat namun masyarakat diberikan kebijakan dalam pengambilan keputusan. Partisipasi masyarakat sangat diperlukan dalam mendukung program pemerintah agar program tersebut dapat berjalan dengan baik. Salah satu program yang perlu melibatkan masyarakat adalah pelestarian kawasan cagar budaya atau kawasan bersejarah.

Pelestarian dalam bidang arsitektur dan lingkungan mulanya berawal dari konsep preservasi yang bersifat statis dengan obyek pelestarian hanya terbatas kepada bangunan saja. Konsep statis tersebut kemudian berkembang menjadi konsep konservasi yang bersifat dinamis, dengan cakupan yang lebih luas meliputi karya arsitektur lingkungan atau kawasan, dan bahkan kota bersejarah (Budiharjo, 1997). Kawasan bersejarah adalah kawasan dengan sekelompok bangunan dan gedung yang terpisah yang diantaranya memiliki kesamaan dalam arsitektur dan nilai historisnya. Kawasan bersejarah di kota-kota di Indonesia biasanya ditetapkan menjadi kawasan cagar budaya melalui Peraturan Daerah sebagai upaya Pemerintah dalam melestarikan kawasan tersebut.

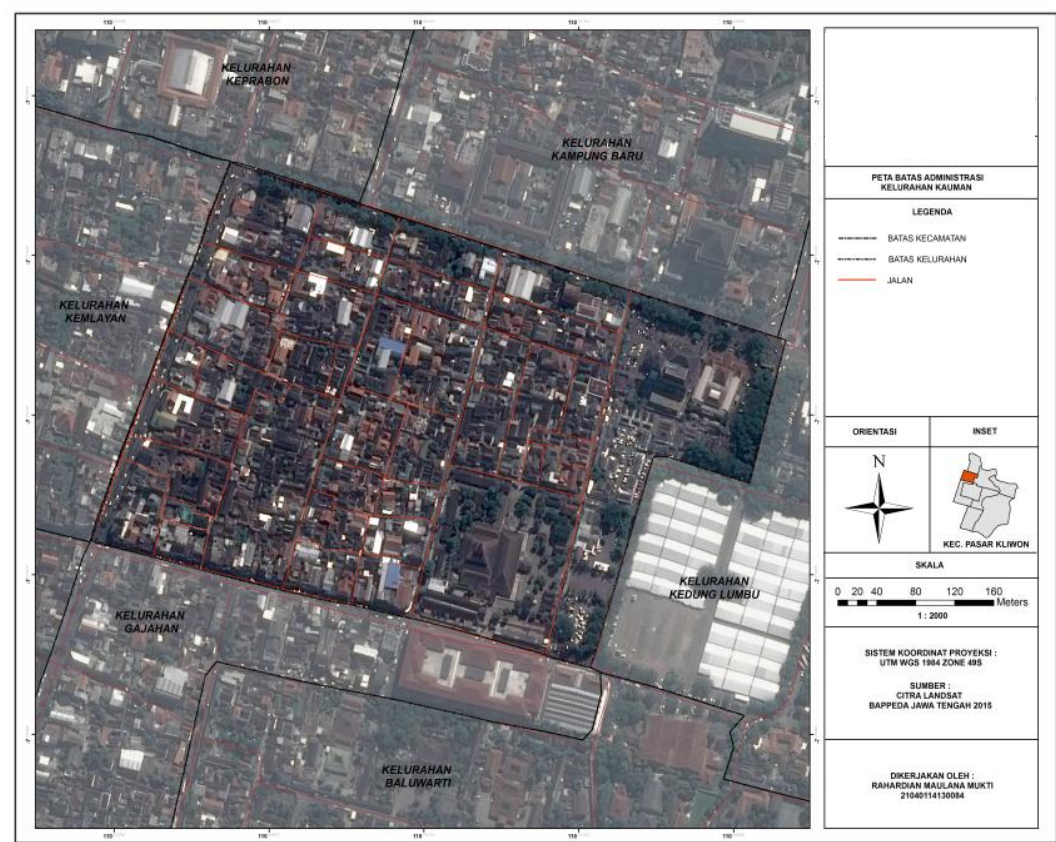

Sumber: Bappeda Provinsi Jawa Tengah, 2015

Gambar 1. Peta Administrasi Kampung Kauman 
Salah satu kawasan bersejarah yang berada di Kota Surakarta yaitu Kampung Kauman. Kawasan Kampung Kauman terletak di Kecamatan Pasar Kliwon yang terletak menyatu dengan Masjid Agung, Alun-alun utara, serta Keraton Surakarta. Kampung Kauman memiliki luas 19,20 Ha yang dibatasi oleh jalan utama yang merupakan kawasan perdagangan dan jasa antara lain Jalan Yos Sudarso dan Jalan Slamet Riyadi. Kampung Kauman merupakan perkampungan santri tradisional kuno yang terletak di tengah kota dengan kekayaan budayanya serta memiliki potensi bersejarah baik dari segi fisik lingkungan berupa bangunan kuno yang masih asli maupun tradisi masyarakat dengan kekhasan religius.

Kampung Kauman merupakan salah satu kampung wisata batik di Kota Surakarta yang didominasi oleh aktivitas industri dan perdagangan batik. Adanya kawasan komersial showroom batik pada Kampung Kauman menyebabkan banyak perubahan fungsi bangunan dengan cara merenovasi bangunan kuno. Terdapat pula beberapa bangunan yang tidak terawat dengan baik dan juga terdapat bangunan yang tidak menjaga keaslian arsitekturnya. Beberapa di antara bangunan tersebut merupakan bangunan kuno yang sebenarnya menarik namun terabaikan sehingga menjadi tidak terawat (Darmadi et al., 2013)

Apabila perubahan fungsi bangunan tidak diawasi maka akan menyebabkan semakin berkurangnya keberadaan bangunan kuno. Selain itu, letak Kampung Kauman yang dekat dengan koridor Jalan Slamet Riyadi dan Jalan Yos Sudarso yang merupakan area bisnis yang strategis di Kota Surakarta dikhawatirkan akan menyebabkan pudarnya karakter Kampung Kauman sebagai kampung bersejarah. Oleh karena itu, diperlukan upaya pelestarian yang melibatkan masyarakat dan dukungan pemerintah. Pelestarian dengan pendekatan bottom up merupakan salah satu cara pelestarian yang memaksa masyarakat untuk berpikir dan bergerak guna merancang dan memutuskan upaya pelestarian yang tepat (Raharjana, 2012). Keterlibatan dan peran serta masyarakat perlu diiikutsertakan dalam pelestarian baik pada tahap perencanaan, pelaksanaan maupun pemeliharaannya (Antariksa, 2015). Masyarakat dinilai lebih mengetahui mengenai isu-isu permasalahan yang ada pada wilayahnya sehingga masyarakat dapat mengambil keputusan dan tindakan yang sesuai dalam upaya pelestarian kampung tersebut Dalam upaya pelestariannya, partisipasi masyarakat juga diperlukan dalam menyediakan sebuah platform untuk mendiskusikan isu dan permasalahan yang ada pada kawasan bersejarah (Dian \& Abdullah, 2013). Oleh karena itu, penelitian ini diharapkan dapat mengidentifikasi bentuk dan tingkat partisipasi masyarakat dalam upaya pelestarian Kampung Kauman sebagai kampung bersejarah.

\section{METODE}

Metode yang digunakan dalam penelitian ini adalah metode kuantitatif. Teknik pengumpulan data yang digunakan adalah pengumpulan data primer dengan menggunakan kuesioner untuk mendapatkan jawaban dari responden. Sedangkan teknik sampling yang digunakan digunakan pada penelitian ini adalah teknik probability sampling atau yang biasa disebut random sampling dengan mengganggap semua populasi memiliki kesempatan yang sama untuk dijadikan sampel. Sampel yang digunakan pada penelitian ini adalah masyarakat Kampung Kauman. Jumlah ukuran sampel yang dibutuhkan dalam penelitian ini dihitung melalui rumus yang diciptakan oleh Slovin, sebagai berikut :

$$
\begin{aligned}
n & =\frac{2618}{1+2618(0.1)^{2}} \\
& =\frac{2618}{27,18} \\
& =96,32 \sim 96
\end{aligned}
$$


Kampung Kauman memiliki jumlah penduduk keseluruhan sebanyak 2618 jiwa pada tahun 2017. Batas toleransi kesalahan yang digunakan dalam pengambilan sampel ini ada $10 \%$. Sehingga berdasarkan rumus Slovin di atas didapatkan jumlah sampel yang digunakan dalam penelitian ini adalah 96 responden masyarakat Kampung Kauman.

Teknik analisis data yang digunakan dalam penelitian ini adalah analisi deskriptif kuantitatif, analisis skoring, analisis tabulasi silang dan uji chi square. Analisis statistik deskriptif digunakan untuk menjelaskan informasi dalam bentuk diagram atau tabel. Analisis skoring digunakan untuk mengklasifikasikan tingkat partisipasi masyarakat sesuai dengan rentang nilai yang telah ditentukan. Sedangkan analisis tabulasi silang dan chi square digunakan untuk mengetahui hubungan antara karakteristik masyarakat dan peran stakeholder terhadap tingkat partisipasi masyarakat. Hubungan antara kedua variabel tersebut dengan tingkat partisipasi masyarakat dapat diketahui melalui kriteria berikut.

Kriteria: $\quad$ Nilai signifikansi $<0,5: \mathrm{H}_{0}$ diterima

Nilai signifikansi $>0,5: \mathrm{H}_{1}$ diterima

Dimana

$\mathrm{H}_{0}$ : terdapat hubungan antara kedua variabel

$\mathrm{H}_{1}$ : tidak terdapat hubungan antara kedua variabel

\section{HASIL DAN PEMBAHASAN}

Analisis partisipasi masyarakat dalam kegiatan pelestarian Kampung Kauman dilakukan melalui 2 tahapan. Tahapan pertama yaitu analisis skoring untuk mengukur tingkat partisipasi individu dalam pelestarian Kampung Kauman. Tahapan selanjutnya adalah analisis tabulasi silang dan uji chi square menggunakan SPSS untuk mengetahui hubungan antara faktor internal (karakteristik masyarakat) dan faktor eksternal (persepsi masyarakat terhadap stakeholder) terhadap tingkat partisipasi masyarakat.

\section{Tingkat Partisipasi Masyarakat dalam Pelestarian Kampung Kauman}

Tingkat partisipasi masyarakat dalam pelestarian Kampung Kauman dapat diketahui melalui tanggapan responden yang berjumlah 96 orang dalam menjawab pertanyaanpertanyaan yang ada dalam kuesioner. Untuk mendapatkan tingkat partisipasi masyarakat maka dilakukan analisis skoring terhadap 9 parameter yang dikemukakan oleh Wilcox (1994) dan Lestrelin et al (2011) antara lain tingkat pengetahuan mengenai sejarah Kampung Kauman, tingkat pengetahuan mengenai kegiatan pelestarian, tingkat kehadiran dalam pertemuan warga, tingkat keaktifan pada saat pertemuan warga, keterlibatan dalam perumusan masalah, keterlibatan dalam pengambilan keputusan, keterlibatan dalam bentuk tenaga, keterlibatan dalam bentuk sumbangan, dan kemampuan warga dalam mengelola kegiatan yang masing-masing parameter memiliki 3 pilihan jawaban. Tingkat partisipasi masyarakat akan terbagi menjadi 3 kelas yaitu sedang, rendah, dan tinggi. Untuk mengkategorisasikan tingkat partisipasi individu maka harus diketahui interval dari setiap kategori melalui rumus berikut :

$$
\begin{aligned}
& \text { Interval }=\frac{\text { skor tertinggi-skorterendah }}{\text { jumlah kelas }} \text { maka, } \\
& \text { Interval }=\frac{27-9}{3}=6
\end{aligned}
$$

Sehingga berdasarkan rumus tersebut akan diklasifikasikan tingkat partisipasi individu sebagai berikut: 
Tabel 1. Klasifikasi Tingkat Partisipasi Masyarakat

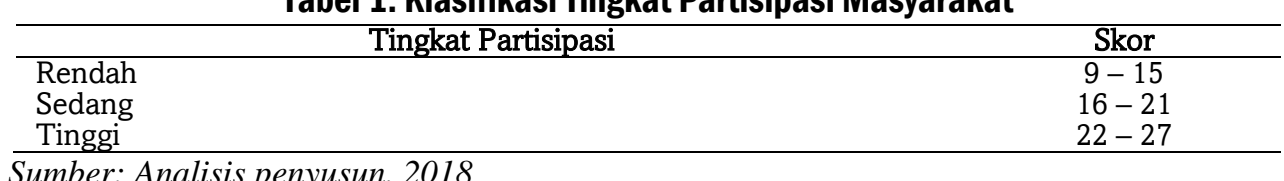

Sumber: Analisis penyusun, 2018

Setelah dilakukan analisis skoring, berikut ini merupakan hasil klasifikasi tingkat partisipasi individu dalam pelestarian Kampung Kauman :

Tabel 2. Tingkat Partisipasi Masyarakat dalam Pelestarian Kampung Kauman

\begin{tabular}{ccc}
\hline Tingkat Partisipasi & Jumlah & Persentase (\%) \\
\hline Rendah & 18 & $18,8 \%$ \\
Sedang & 58 & $60,4 \%$ \\
Tinggi & 20 & $20,8 \%$ \\
\hline
\end{tabular}

Sumber: Analisis penyusun, 2018

Berdasarkan tabel di atas, dapat diketahui bahwa sebagian besar masyarakat yang berjumlah 58 orang atau $60,4 \%$ berada pada tingkat partisipasi sedang. Tingkat partisipasi sedang memiliki karakteristik dimana individu memiliki pengetahuan yang cukup mengenai sejarah Kampung Kauman dan pemahaman mengenai pentingnya pelestarian Kampung Kauman, jarang menghadiri pertemuan warga, cukup aktif dalam diskusi, cukup terlibat dalam perumusan masalah, tidak terlalu terlibat dalam pengambilan keputusan, namun aktif dalam berkontribusi dalam bentuk sumbangan uang dan tenaga.

Masyarakat yang termasuk dalam tingkat partisipasi tinggi berjumah 20 orang atau $20,8 \%$ dari total keseluruhan. Tingkat partisipasi tinggi memiliki karakteristik dimana mayoritas individu memiliki pengetahuan yang cukup mengenai sejarah Kampung Kauman dan pemahaman mengenai pentingnya pelestarian Kampung Kauman, selalu menghadiri pertemuan warga, sangat aktif dalam diskusi dengan memberikan usulan atau pendapat, terlibat dalam perumusan masalah, terlibat dalam pengambilan keputusan, serta aktif dalam berkontribusi dalam bentuk sumbangan uang dan tenaga.

Selain itu, juga terdapat masyarakat yang memiliki tingkat partisipasi rendah yaitu berjumlah 18 orang atau $18,8 \%$ dari total keseluruhan. Tingkat partisipasi rendah memiliki karakteristik dimana mayoritas individu tidak mengetahui sejarah Kampung Kauman tetapi cukup memahami pentingnya pelestarian Kampung Kauman, jarang menghadiri pertemuan warga, hanya menyimak jalannya diskusi, tidak terlibat dalam perumusan masalah, tidak terlibat dalam pengambilan keputusan, namun aktif dalam memberikan sumbangan dalam bentuk uang dan tenaga. Sehingga dapat disimpulkan bahwa sebagian besar masyarakat Kampung Kauman terlibat dalam kegiatan pelestarian Kampung Kauman walaupun memiliki tingkat partisipasi yang berbeda-beda. Mayoritas masyarakat terlibat dalam pelaksanaan kegiatan pelestarian Kampung Kauman melalui kontribusi sumbangan berupa uang dan tenaga. Perbedaan tingkat partisipasi antar individu terlihat pada saat tahap perumusan masalah, keaktifan diskusi, dan pengambilan keputusan.

\section{Hubungan antara Faktor Internal dan Tingkat Partisipasi Masyarakat dalam Pelestarian Kampung Kauman}

Faktor yang mempengaruhi keterlibatan masyarakat dalam suatu kegiatan dibedakan menjadi 2 jenis yaitu faktor internal dan faktor eksternal. Menurut Slamet (1994), faktor internal yang mempengaruhi partisipasi masyarakat adalah berasal dari dalam kelompok masyarakat itu sendiri. Secara teoritis, terdapat hubungan antara ciri-ciri individu dengan tingkat partisipasi, seperti usia, jenis kelamin, tingkat pendidikan, jenis pekerjaan,dan besarnya pendapatan, dan lamanya menjadi anggota masyarakat akan sangat berpengaruh 
pada partisipasi masyarakat. Untuk mengetahui hubungan antara faktor internal atau karakteristik masyarakat terhadap tingkat partisipasi masyarakat maka dilakukan analisis tabulasi silang dan uji chi square menggunakan SPSS. Apabila nilai signifikansi kurang dari $0,05(5 \%)$ maka H0 ditolak yang berarti terdapat hubungan antara kedua variabel. Sedangkan apabila nilai signifikansi lebih dari 0,05 (5\%) maka $\mathrm{H}_{0}$ diterima yang berarti tidak terdapat hubungan antara kedua variabel. Berikut ini merupakan hasil analisis SPSS antara karakteristik masyarakat terhadap tingkat partisipasi masyarakat.

Tabel 3. Hubungan antara Faktor Internal dan Tingkat Partisipasi Masyarakat

\begin{tabular}{lcc}
\hline Karakteristik Masyarakat & Nilai Signifikansi & Keterangan \\
\hline Jenis Kelamin & 0,003 & Ada hubungan \\
Usia & 0,173 & Tidak ada hubungan \\
Tingkat Pendidikan & 0 & Ada hubungan \\
Mata Pencaharian & 0,131 & Tidak ada hubungan \\
Tingkat Penghasilan & 0,217 & Tidak ada hubungan \\
Lama tinggal & 0 & Ada hubungan \\
\hline
\end{tabular}

Sumber: Analisis penyusun, 2018

Berdasarkan hasil uji SPSS di atas, maka dapat diketahui hubungan antara faktor internal atau karakteristik masyarakat terhadap bentuk dan tingkat partisipasi masyarakat. Variabel yang memiliki hubungan terhadap bentuk dan tingkat partisipasi masyarakat antara lain jenis kelamin, tingkat pendidikan, dan lama tinggal. Hal tersebut dikarenakan nilai signifikansi ketiga variabel tersebut lebih kecil dari $0,05(5 \%)$ sehingga $\mathrm{H}_{0}$ ditolak yang berarti terdapat hubungan dengan bentuk dan tingkat partisipasi masyarakat. Variabel jenis kelamin juga memiliki hubungan dengan tingkat partisipasi masyarakat karena mayoritas responden dengan jenis kelamin laki-laki berada pada tingkat partisipasi sedang dan tinggi. Sebaliknya, mayoritas responden dengan jenis kelamin perempuan mendominasi pada tingkat partisipasi rendah. Dapat disimpulkan bahwa responden dengan jenis kelamin lakilaki lebih aktif berpartisipasi dalam pelestarian Kampung Kauman karena jenis kelamin seseorang berkaitan dengan kemampuan seseorang dalam terlibat dalam suatu kegiatan.

Variabel tingkat pendidikan memiliki hubungan dengan bentuk dan tingkat partisipasi masyarakat karena responden dengan tingkat pendidikan tamat SD memiliki persentase tertinggi pada tingkat partisipasi rendah. Responden dengan tingkat pendidikan tamat SMA memiliki persentase tertinggi pada tingkat partisipasi sedang. Sedangkan responden dengan tingkat pendidikan tamat sarjana memiliki persentase tertinggi pada tingkat partisipasi tinggi. Dapat disimpulkan bahwa semakin rendah tingkat pendidikan responden maka akan semakin rendah pula keaktifan dalam berpartisipasi karena dengan latar belakang pendidikan yang berbeda akan mempengaruhi kemampuan seseorang dalam bekerja sama atau terlibat dalam suatu kegiatan bersama anggota masyarakat lainnya.

Variabel lama tinggal juga memiliki hubungan dengan tingkat partisipasi masyarakat karena mayoritas responden yang tinggal lebih lama baik sejak lahir maupun lebih dari 10 tahun memiliki persentase yang tinggi pada tingkat partisipasi sedang dan tinggi. Sehingga dapat disimpulkan bahwa semakin lama responden yang tinggal di Kampung Kauman maka akan semakin tinggi pula keaktifan dalam berpartisipasi karena semakin lama seseorang tinggal pada suatu tempat maka akan meningkatkan rasa memiliki terhadap tempat tersebut yang selanjutnya akan mempengaruhi kemauan seseorang untuk terlibat dalam kegiatan khususnya kegiatan pelestarian Kampung Kauman. Namun, terdapat juga variabel yang tidak memiliki hubungan dengan partisipasi masyarakat antara lain usia, mata pencaharian dan tingkat penghasilan. Hal tersebut dikarenakan nilai signifikansi ketiga variabel tersebut lebih besar dari $0,05(5 \%)$ sehingga $\mathrm{H}_{0}$ diterima yang berarti tidak 
ada hubungan dengan partisipasi masyarakat.

\section{Hubungan antara Faktor Eksternal dan Tingkat Partisipasi Masyarakat dalam Pelestarian Kampung Kauman}

Faktor eksternal yaitu faktor yang bersal dari luar diri individu. Faktor eksternal yang mempengaruhi partisipasi seseorang adalah hubungan pengelola kegiatan dengan sasaran dan pengelola kegiatan. Menurut Sunarti (2003), faktor-faktor eksternal yang mempengaruhi keterlibatan seseorang adalah stakeholder atau petaruh kunci yaitu semua pihak yang berkepentingan dan mempunyai pengaruh terhadap suatu kegiatan. Petaruh kunci adalah siapa yang mempunyai pengaruh yang sangat signifikan, atau mempunyai posisi penting guna kesuksesan program. Stakeholder yang terlibat dalam pelestarian Kampung Kauman antara lain pemerintah kota, pihak kelurahan, tokoh masyarakat dan paguyuban Batik Kauman. Untuk mengetahui hubungan antara faktor eksternal atau peran stakeholder terhadap bentuk dan tingkat partisipasi masyarakat maka dilakukan analisis tabulasi silang dan uji chi square menggunakan SPSS seperti yang telah dijelaskan sebelumnya. Apabila nilai signifikansi kurang dari 0,05 (5\%) maka $\mathrm{H}_{0}$ ditolak yang berarti terdapat hubungan antara kedua variabel. Sedangkan apabila nilai signifikansi lebih dari $0,05(5 \%)$ maka $\mathrm{H}_{0}$ diterima yang berarti tidak terdapat hubungan antara kedua variabel. Berikut ini merupakan hasil analisis SPSS antara peran stakeholder terhadap bentuk dan tingkat partisipasi masyarakat

Tabel 4. Hubungan antara Faktor Eksternal dan Tingkat Partisipasi Masyarakat

\begin{tabular}{lcc}
\hline Peran Stakeholder & Nilai Signifikansi & Keterangan \\
\hline Pemerintah kota & 0,119 & Tidak ada hubungan \\
Pihak kelurahan & 0,041 & Ada hubungan \\
Tokoh masyarakat & 0,023 & Ada hubungan \\
Paguyuban Batik Kauman & 0,121 & Tidak ada hubungan \\
\hline Sumber: Analisis penyusun, 2018 & &
\end{tabular}

Dalam kegiatan pelestarian Kampung Kauman stakeholder yang terlibat antara lain pemerintah kota, pihak kelurahan, tokoh masyarakat, dan paguyuban Batik Kauman. Berdasarkan hasil uji SPSS, maka dapat diketahui hubungan antara peran stakeholder terhadap bentuk dan tingkat partisipasi masyarakat. Variabel yang memiliki hubungan terhadap tingkat partisipasi masyarakat adalah peran pemerintah kelurahan dan tokoh masyarakat. Hal tersebut dikarenakan variabel tersebut memiliki nilai signifikansi yang lebih kecil dari $0,05(5 \%)$ sehingga $\mathrm{H}_{0}$ ditolak yang berarti terdapat hubungan dengan bentuk dan tingkat partisipasi masyarakat.

Variabel peran pihak kelurahan memiliki hubungan dengan tingkat partisipasi masyarakat karena terdapat pengaruh yang signifikan terhadap tingkat partisipasi masyarakat. Responden yang memiliki persepsi kurang baik terhadap peran pihak kelurahan berada pada tingkat partisipasi rendah. Sebaliknya, mayoritas responden yang memiliki persepsi cukup dan baik terhadap peran pihak kelurahan berada pada tingkat partisipasi sedang dan tinggi. Dapat disimpulkan bahwa semakin buruk persepsi responden terhadap pihak kelurahan maka semakin rendah pula keaktifannya dalam berpartisipasi pada kegiatan pelestarian Kampung Kauman.

Variabel peran tokoh masyarakat juga memiliki hubungan dengan bentuk dan tingkat partisipasi masyarakat. Mayoritas responden yang memiliki persepsi kurang baik terhadap peran tokoh masyarakat berada pada tingkat partisipasi rendah dan sedang. Sedangkan mayoritas responden yang memiliki persepsi cukup dan baik terhadap peran tokoh masyarakat berada pada tingkat partisipasi sedang dan tinggi. Dapat disimpulkan bahwa semakin buruk persepsi responden terhadap peran tokoh masyarakat maka semakin 
rendah pula keaktifannya dalam berpartisipasi pada kegiatan pelestarian Kampung Kauman.

Adanya hubungan antara peran pihak kelurahan, dan tokoh masyarakat, terhadap partisipasi masyarakat dikarenakan kedua pihak tersebut merupakan stakeholder yang paling dekat dan intens dengan masyarakat. Pihak kelurahan yang merupakan fasilitator cukup aktif dalam mengajak masyarakat untuk berpartisipasi dalam kegiatan pelestarian Kampung Kauman terutama dalam menerima usulan atau pendapat mengenai permasalahan yang ada di Kampung Kauman. Sedangkan peran tokoh masyarakat memiliki pengaruh terhadap tingkat partisipasi masyarakat karena tokoh masyarakat sebagai teladan anggota masyarakatnya aktif dalam mengajak masyarakat untuk berpartisipasi dalam kegiatan pelestarian Kampung Kauman seperti kegiatan kerja bakti dan pertemuan warga yang diadakan secara rutin.

\section{KESIMPULAN}

Mayoritas responden yaitu sebesar $60,4 \%$ berada pada tingkatan sedang, 20,8\% berada pada tingkat partisipasi sedang, dan 18,8\% responden berada pada tingkat partisipasi rendah. Berdasarkan analisis tabulasi silang dan uji chi square menggunakan SPSS, faktor internal atau karakteristik masyarakat yang memiliki hubungan terhadap tingkat partisipasi masyarakat yaitu jenis kelamin, tingkat pendidikan, dan lama tinggal. Jenis kelamin memiliki hubungan dengan tingkat partisipasi yang diberikan karena jenis kelamin seseorang berkaitan dengan kemampuan seseorang dalam terlibat dalam suatu kegiatan. Tingkat pendidikan memiliki hubungan terhadap bentuk dan tingkat partisipasi masyarakat karena dengan latar belakang pendidikan yang berbeda akan mempengaruhi kemampuan seseorang dalam bekerja sama atau terlibat dalam suatu kegiatan bersama anggota masyarakat lainnya. Lama tinggal juga memiliki hubungan terhadap tingkat partisipasi masyarakat karena semakin lama seseorang tinggal pada suatu tempat maka akan meningkatkan rasa memiliki terhadap tempat tersebut yang selanjutnya akan mempengaruhi kemauan seseorang untuk terlibat dalam kegiatan khususnya kegiatan pelestarian Kampung Kauman.

Berdasarkan analisis tabulasi silang dan uji chi square menggunakan SPSS, faktor eksternal atau peran stakeholder yang memiliki hubungan dengan tingkat partisipasi masyarakat yaitu peran pihak kelurahan dan peran tokoh masyarakat, Hal tersebut dikarenakan kedua pihak tersebut merupakan stakeholder yang paling dekat dan intens dalam mengajak masyarakat untuk terlibat dalam kegiatan pelestarian Kampung Kauman. Pihak kelurahan juga berperan sebagai fasilitator yang menampung segala usulan masyarakat mengenai permasalahan yang ada di Kampung Kauman. Sedangkan tokoh masyarakat merupakan teladan bagi anggota masyarakat lainnya sehingga mampu mempengaruhi masyarakat untuk terlibat dalam kegiatan pelestarian Kampung Kauman.

\section{DAFTAR PUSTAKA}

Antariksa. (2015). Pelestarian Arsitektur dan Kota yang Terpadu. Yogyakarta: Cahaya Atma Pustaka.

Budiharjo, E. (1997). Arsitektur Pembangunan dan Konservasi. Jakarta: Djambatan.

Darmadi et al. (2013). Perubahan Fungsi Ruang Rumah Kuno di Kampung Kauman Surakarta. Sinektika, 13 No. 2, 76-82.

Dian, A. M., \& Abdullah, N. C. (2013). Public Participation in Heritage Sites Conservation in Malaysia : Issues and challenges. Procedia - Social and Behavioral Sciences, 101, 248-255. http://doi.org/10.1016/j.sbspro.2013.07.198

Lestrelin et al. (2011). Measuring participation : Case studies on village land use planning in northern Lao PDR. Applied Geography, 31(3), 950-958. http://doi.org/10.1016/j.apgeog.2011.01.003

Omar, et al. (2016). Youth Participation in Urban Neighbourhood Community. Procedia - Social and Behavioral Sciences, 234, 309-316. http://doi.org/10.1016/j.sbspro.2016.10.247

Prabhakaran et al. (2014). Community participation in rural tourism: Towards a conceptual framework. 
Procedia - Social and Behavioral Sciences, 144, 290-295. http://doi.org/10.1016/j.sbspro.2014.07.298 Slamet, Y. (1994). Pembangunan Masyarakat Berwawasan Partisipasi. Surakarta: Sebelas Maret University Press.

Sunarti. (2003). Partisipasi Masyarakat dalam Pembangunan Perumahan Secara Berkelompok. Tata Loka, 5 No. $1,2$.

Wilcox, D. (1994). Community Participation and Empowerment : Putting Theory into Practice. New York. 